\title{
Molecular Detection and Characterization of China Aster (Callistephus chinensis L. Nees.) Phyllody Phytoplasma
}

\author{
Mahalingappa Bandakkanavara ${ }^{1}$, H.A. Prameela ${ }^{1}$, Santosh Mali ${ }^{2}$, \\ Manjunath, S. Hurakadli ${ }^{1}$, S. Basavaraj ${ }^{1}$, Kedarnath ${ }^{1}$, \\ Raghavendra Achari ${ }^{1}$ and K.T. Rangaswamy ${ }^{1}$ \\ ${ }^{1}$ Department of Plant Pathology, ${ }^{2}$ Department of Agricultural Entomology, College of \\ Agriculture, UAS, GKVK, Bengaluru-560065, India \\ *Corresponding author
}

\section{Keywords}

Phytoplasma, Phyllody, China aster, Molecular and detection

Article Info

Accepted:

25 July 2019

Available Online:

10 August 2019

\section{A B S T R A C T}

China aster (Callistephus chinensis L. Nees.) is one of the important flower crop in India. It belongs to the family Asteraceae is native to China. Phyllody disease in China aster was first reported during 1986 from Bengaluru, India and known to be transmitted by Orosius albicinctus. The disease was characterized by chlorosis, upright growth, small leaf, short internode, stunting, profuse vegetative growth and phyllody (transformation of floral organs into leaf-like structures). Molecular detection was carried out through PCR assay by extracting the total DNA from phyllody infected aster leaf by using nested PCR phytoplasma specific universal primers R16F2n/R16FR2and results revealed that the amplification of phytoplasmal specific PCR product of $1.2 \mathrm{~kb}$ fragment corresponding to the 16S rDNA. A 16S rDNA sequence comparison of aster phyllody phytoplasma with the 16S rDNA gene sequences of other phytoplasmas obtained from NCBI database. The BLAST analysis revealed that aster phyllody phytoplasma had 99 per cent sequence similarity with Tomato big bud TBB1 (KX358564.1), Alfalfa phytoplasma (Sudan) AP2 (KY449416.1), Pisumsativum phyllody (KX358571.1) phytoplasma. Furthermore, the phylogenetic tree constructed by using the software MEGA 6.06 showed that aster phyllody phytoplasma clustered with the Tomato big bud TBB1 (KX358564.1) phytoplasma. The characterization of the phytoplasma through phylogenetic analysis of nucleotide sequence of $16 \mathrm{~S}$ rDNA region showed that niger phyllody phytoplasma belong to $16 \mathrm{~S}$ rII phytoplasmal group.

\section{Introduction}

China aster (Callistephus chinensis L. Nees.) belongs to the family Asteraceae is native to China having excellent unparallel distinguish attractive colours used for cut flower, potted plants and garden decoration. In India china aster occupied approximately 5000 ha and grown in few states like Maharastra, Karnataka, Tamil Nadu, West Bengal and Andhra Pradesh (Anonymous, 2009). The flowers have long vase life and used for various decorative purposes. In India, it is grown successfully during kharif, rabi as well 
as summer seasons for year-round production (Singh, 2006). China aster is also an important commercial flower crop of Siberia, Russia, Japan, North America, Switzerland and Europe. In India, it is grown in an area of 3500 ha with the productivity of 10-12 tonnes/ha. The china aster area, production and productivity has however remained virtually stagnant over recent decades as the crop suffers from many diseases like Fungal wilt, Collar rot, Grey mould, Rust, Leaf spot, Stem rot, Canker and bacterial wilt. Among the major constraints, phyllody is a serious disease in most China aster growing regions (Singh, 2006). Recently, phyllody symptoms in China aster plants have been frequently observed in several fields of the India. Phyllody disease on China aster was first reported during 1986 from Bengaluru, India and known to be transmitted by Orosius albicinctus (Rangaswamy et al., 1988). The disease was characterized by chlorosis, upright growth, small leaf, short internode, stunting, profuse vegetative growth and phyllody flower (transformation of floral organs into leaf-like structures). However little attempts have been made on the characterization of the phytoplasma. Therefore, present work carried out to understand the molecular relationship of China aster phyllody phytoplasma with other phytoplasmas diseases.

\section{Materials and Methods}

\section{Sources of infected china aster plants}

Samples were collected from naturally infected china aster plants showing typically phyllody symptoms and healthy china aster plant.

\section{DNA (total genomic) extraction}

The phytoplasma infected china aster plant samples were collected from field. Total nucleic acid was isolated from infected plant leaf tissue and healthy leaf tissue by modified Cetyl Trimethyl Ammonium Bromide (CTAB) (Sunard et al., 1991) method and used for PCR amplification by using degenerated oligonucleotide universal primers (Deng and Hiruki, 1991). The DNA concentrations were measured with Nanodrop Spectrophotometer.

\section{Polymerase chain reaction}

The DNA obtained was subjected to PCR amplification using primer designed to amplify $16 \mathrm{~S}$ rDNA from the infected china asterplants. PCR amplifications were conducted using phytoplasma specific universal P1/P7 and nested PCR primer $\mathrm{R} 16 \mathrm{~F} 2 \mathrm{n} / \mathrm{R} 16 \mathrm{FR} 2 \mathrm{The}$ mixture was subjected to initial denaturation at $95^{\circ} \mathrm{C}$ for 5 minutes followed by 35 cycles of denaturation at $95^{\circ} \mathrm{C}$ for 1 minute, primer annealing at $55^{\circ} \mathrm{C}$ for 1 minute, primer extension at $72{ }^{\circ} \mathrm{C}$ for 2 minute and finally at $72{ }^{\circ} \mathrm{C}$ for $10 \mathrm{~min}$ for final primer extension. After completion of the reaction, the products were kept at $4{ }^{\circ} \mathrm{C}$ prior to electrophorosis.

\section{Analysis of PCR products by agarose gel electrophoresis}

Amplification was confirmed by agarose gel electrophoresis.

\section{Sequencing and sequence analysis of $16 \mathrm{~S}$} rDNA

The products were sent to Chromous Biotech Pvt. Ltd., Bengaluru for the sequencing by Sanger's primer walking method. Sequencing was done in both directions using forward and reverse primers. The sequences retrieved were subjected to BLAST analysis.

\section{Phylogenetic analysis}

The sequence homology obtained in BLAST (www.ncbi.nih.gov /BLAST) and Neighbor 
joining phylogenetic tree was generated using MEGA 6.06 software tool.

\section{Results and Discussion}

The affected plants showed different types of phyllody disease symptoms. The affected plant showed slight yellowing along the vein followed by proliferation of short upright branches. In advanced stages of infection severe reduction in leaf size and profuse vegetative growth were observed. All the flowers developed into vegetative structures (phyllody). Occasionally partial phyllody was also noticed wherein, a few affected branches showed phyllody flower while the remaining branches produced normal flowers(Plate 1).

Polymerase chain reaction was employed to establish association of phytoplasma using phytoplasma universal primers $\mathrm{P} 1 / \mathrm{P} 7$ and nested PCR primers R16F2n/R16R2 were designed to amplify phytoplasmal $16 \mathrm{~S}$ rDNA. The phytoplasmal DNA was not amplified when standard PCR protocol was used as suggested by the Lee et al., (1993) and the PCR protocol was slightly modified by altering the PCR conditions i.e. annealing temperature of $55{ }^{\circ} \mathrm{C}$ for one minute was found suitable for amplifying aster phyllody phytoplasmal DNA as compared to $48{ }^{\circ} \mathrm{C}$ of standard PCR protocols suggested by various earlier workers.

The total DNA extracted from the symptomatic and asymptomatic china aster plants were subjected to PCR amplification using the phytoplasma- specific universal primer pair P1/P7. The PCR products were subjected to the electrophorosis in a 1.0 per cent agarose gel, stained with ethidium bromide and observed under UV transilluminator.

In order to identify the association of $16 \mathrm{~S}$ rDNA groups to which these phytoplasmas belongs and also to know their relationship at molecular level, nested PCR was performed using phytoplasma specific universal primers $\mathrm{R} 16 \mathrm{~F} 2 \mathrm{n} / \mathrm{R} 16 \mathrm{FR} 2$. When the first round PCR products were reamplified in nested PCR assay using primersR16F2n/R16R2. A product of DNA fragment of $1.2 \mathrm{~kb}$ size was obtained in the diseased china aster samples and a known phytoplasma positive sample (periwinkle phyllody) but not in healthy plant sample. This indicated the association of phytoplasmal agent with china aster phyllody disease (Plate 2).

\section{Characterization of china aster phyllody phytoplasma}

\section{The 16S rDNA sequence analysis of china aster phyllody phytoplasma}

A 16S rDNA sequence comparison of aster phyllody phytoplasma with the $16 \mathrm{~S}$ rDNA gene sequences of other phytoplasmas obtained from NCBI database. The BLAST analysis revealed that aster phyllody phytoplasma had 99 per cent sequence similarity with Tomato big bud TBB1 (KX358564.1), Alfalfa phytoplasma (Sudan) AP2(KY449416.1), Pisum sativum phyllody (KX358571.1) phytoplasma (Table 1). Furthermore, the phylogenetic tree constructed by using the software MEGA 6.06 showed that aster phyllody phytoplasma clustered with the Tomato big bud TBB1 (KX358564.1) phytoplasma (Fig. 1).

The disease was characterized by chlorosis, upright growth, small leaf, short internode, stunting, profuse vegetative growth and phyllody flower(transformation of floral organs into leaf-like structures). Phyllody disease on China aster was first reported during 1986 from Bengaluru, India and known to be transmitted by Orosius albicinctus (Rangaswamy etal., 1988). 
Table.1 Phylogenetic analysis of aster 16S rDNA gene with different phytoplasmal strains

\begin{tabular}{|c|l|c|c|}
\hline $\begin{array}{c}\text { SI. } \\
\text { No. }\end{array}$ & \multicolumn{1}{|c|}{ Phytoplasma strain } & $\begin{array}{c}\text { Accession } \\
\text { number }\end{array}$ & $\begin{array}{c}\text { Max. } \\
\text { identity(\%) }\end{array}$ \\
\hline $\mathbf{1}$ & Alfalfa phytoplasma (Sudan) AP2 & KY449416.1 & 99 \\
\hline $\mathbf{2}$ & Pisumsativum phyllody & KX358571.1 & \\
\hline $\mathbf{3}$ & Tomato big bud TBB1 & KF975588.1 \\
\hline $\mathbf{4}$ & Medicagosativa phytoplasma & KX358564.1 \\
\hline $\mathbf{5}$ & Sesamumindicum phyllody & KX358563.1 \\
\hline $\mathbf{6}$ & Brinjal little leaf & KX689253.1 \\
\hline $\mathbf{7}$ & Tomato big bud phytoplasma KA-52 & KP027532.1 \\
\hline $\mathbf{8}$ & 'Helianthusannuus' phyllody HAP1 & KT005455.1 \\
\hline $\mathbf{9}$ & Bell pepper big bud BPBB2 & KR706444.1 \\
\hline $\mathbf{1 0}$ & 'Corchorusolitorius' phytoplasma JPHY3 & KM103730.1 & \\
\hline $\mathbf{1 1}$ & Sweet potato little leaf & EU003536.1 & \multirow{2}{*}{98} \\
\hline $\mathbf{1 2}$ & Chickpea phyllody & KX151133.1 \\
\hline $\mathbf{1 3}$ & Candidatus Phytoplasma aurantifolia OS-KATm-BP & KU052831.1 & \\
\hline $\mathbf{1 4}$ & Soybean witches'-broom & KC508646.1 & \\
\hline $\mathbf{1 5}$ & Candidatus Phytoplasma aurantifolia VCP & JQ868437.1 & \multirow{2}{*}{97} \\
\hline $\mathbf{1 6}$ & Soybean phyllody & EF193353.1 & \\
\hline $\mathbf{1 7}$ & Cauliflower stunt & JN818845.1 & 96 \\
\hline $\mathbf{1 8}$ & Milkweed yellows & AF510724.1 & 91 \\
\hline $\mathbf{1 9}$ & Clover yellow edge phytoplasma & AF189288.1 \\
\hline $\mathbf{2 0}$ & Soybean veinal necrosis phytoplasma & AF177383.1 & \\
\hline & & \\
\hline
\end{tabular}

Figure.1 Phylogenetic tree constructed by maximum parsimony method using 16S rDNA sequences of china aster phyllody Phytoplasma and other phytoplasmal strains

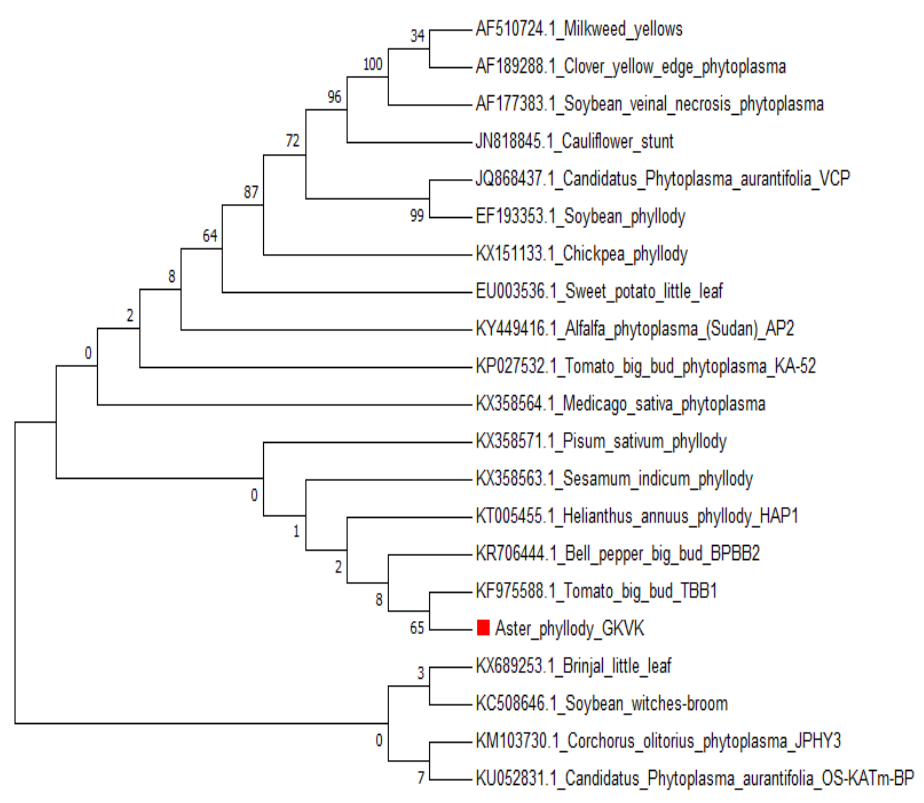


Plate.1 Phyllody symptoms on naturally infected aster plants

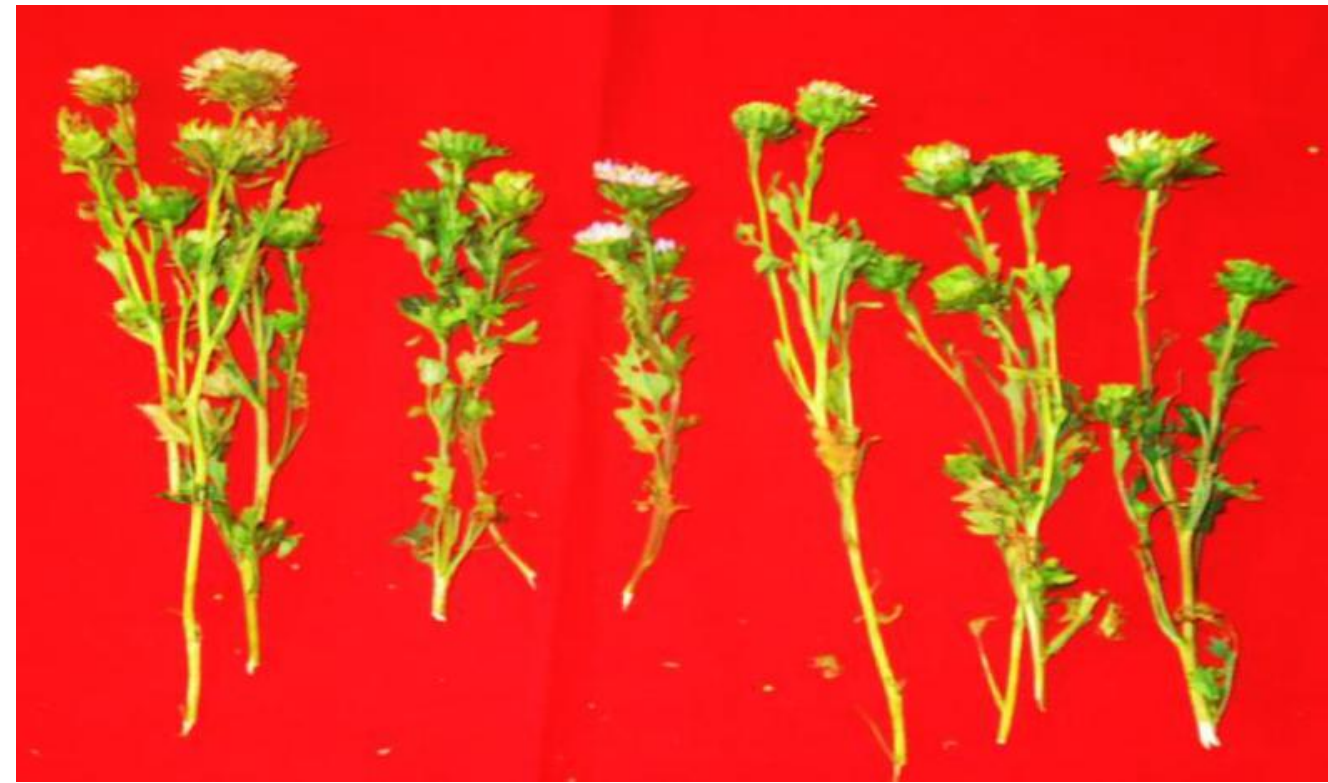

Phyllody infected aster plants

Plate.2 Nested- PCR amplification of 16S rDNA of aster phyllody Phytoplasma

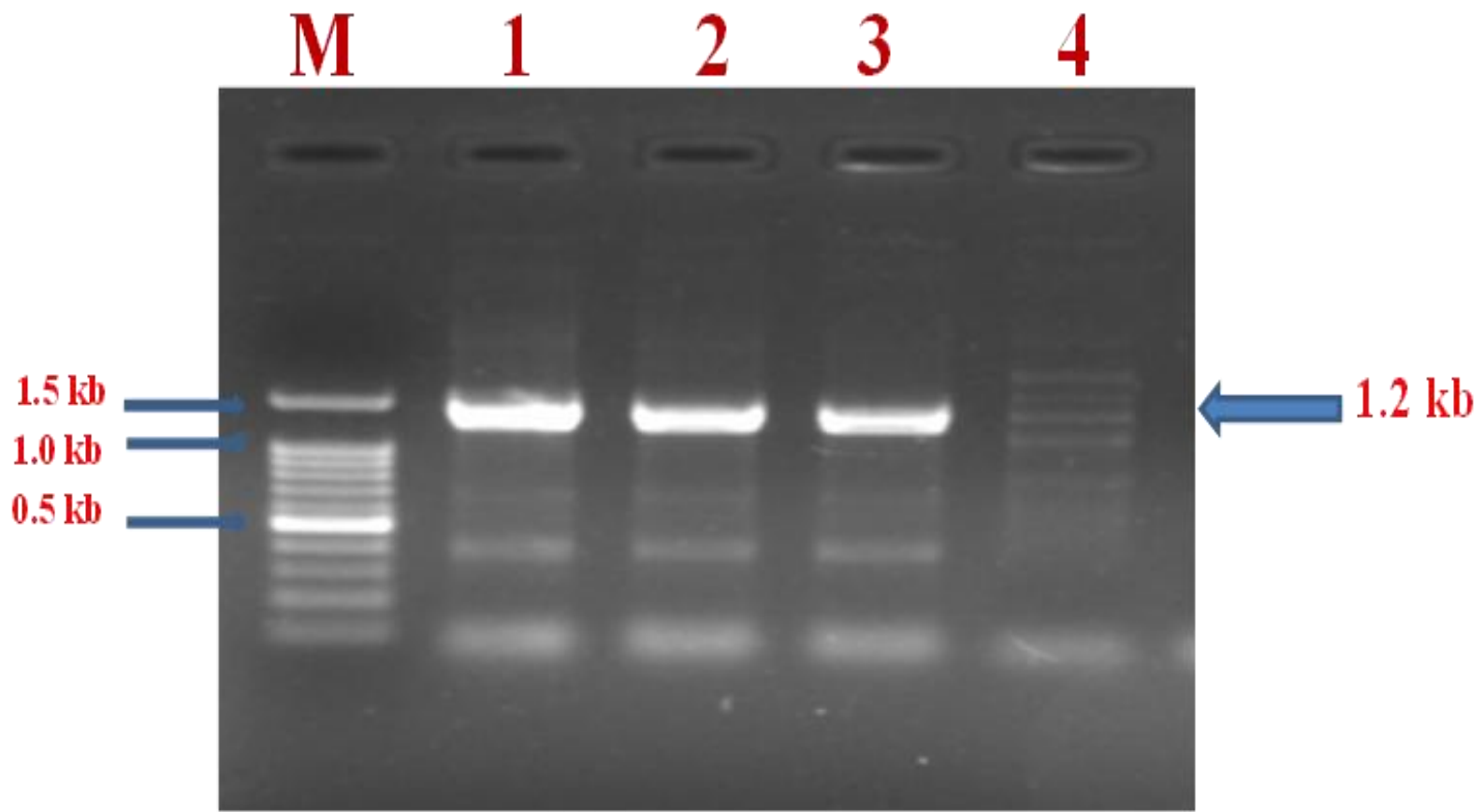

Lane M: 1.5 kb Ladder, Lane 1 and 2: China aster phyllody phytoplasmal DNA, Lane 3: Positive sample (Periwinkle phyllody), Lane 4: Healthy china aster plant DNA

In the present study, aster phyllody phytoplasma DNA was subjected to PCR amplification by using the universal primer P1/P7 which did not amplified the presence of phytoplasma in infected and healthy aster plant samples or no visible product was amplified by PCR from samples obtained from aster phyllody and also in positive 
samples. This might be due to the presence of low level of DNA concentration below the detection in ethidium bromide-stained agarose gel. Further, first round PCR product was subjected to nested PCR, which yielded a DNA fragment of $1.2 \mathrm{~kb}$ in infected and positive control (periwinkle phyllody) but negative in asymptomatic plant. These result are in agreement with the earlier work of Bhat etal., 2005; Kaminskaetal., 2012; Madhupriyaetal., 2013. It suggested the association of a phytoplasma with the diseased plants. The nested primers are designed for the conserved region of the phytoplasmas and found highly specific to the phytoplasmal 16S rDNA.

Nested primer analysis using the primer pair R16F2n/ R16R2 greatly increases the sensitivity in detection of phytoplasmas even when the phytoplasma titters are very low and in which phytoplasmas are unevenly distributed (Gundersen and Lee, 1996). Normal as well as nested PCR technique has been employed by various workers for the detection of phytoplasma in the phytoplasma affected crop plants (Lee et al., 1993; Raj et al., 2006). By nested PCR assay using universal primers R16F2n/ R16R2, a PCR product of $1250 \mathrm{bp}$ corresponding to the intergenic transcribed spacer region of the phytoplasma was detected indicating the association of phytoplasmal agent in aster phyllody disease infected plant samples.

The 16S rRNA gene is the most widely used marker in the phytoplasma research community which allow amplification of $>1200 \mathrm{bp}$ to near full-length 16S rDNA gene sequences of all phytoplasmas associated with various plants and proves to be very useful in preliminary classification of phytoplasmas (Lee et al., 1993; Namba et al., 1993; Schneider et al., 1993; Gundersen and Lee, 1996; Smart et al., 1996). The merits of the $16 \mathrm{~S}$ rDNA gene-based system for phytoplasma classification lie in its property of highly conserved nature, so that the universal oligonucleotide primers are relatively easily designed. The wealth of sequences available in the Gene Bank database, which makes it plausible to conduct comprehensive phylogenetic studies.

A 16S rDNA sequencecomparison of aster phyllody phytoplasma with the $16 \mathrm{~S}$ rDNA gene sequences of other phytoplasmas obtained from NCBI database indicated that the phytoplasma detected in aster phyllody phytoplasma shared maximum sequence similarity of 99 per cent with Tomato big bud TBB1 (KX358564.1) phytoplasma which belonging to $16 \mathrm{SrII}$ group. Furthermore, the phylogenetic tree constructed also showed that, the aster phyllody phytoplasma clustered with the Tomato big bud TBB1 (KX358564.1) phytoplasma. This result are in agreement with earlier report of Mahadevakumar (2017) who reported the aster phyllody phytoplasma shared 99 per cent similarity with $C a$. P. australasia strains (AB257291) and was identical to the members of 16SrII-D group phytoplasmas.

\section{References}

Anonymous (2009). Statistical data on agricultural crops in Karnataka State, Department of Agriculture, Govt. of Karnataka. 43pp.

Bhat, A. I., Madhubala, R., Hareesh, P. S. and Anandaraj, M. (2006). Detection and characterization of the phytoplasma associated with a phyllody disease of black pepper (Piper nigrum L.) in India. Sci. Horti., 107: 200-204.

Deng, S. and Hiruki, D. (1991). Amplification of 16Sr DNA genes from culturable and non-culturable mollicutes. J. Microbial. Methods, 14: 53-61.

Gundersen, D. E. and Lee, I. M. (1996). Ultra- sensitive detection of 
phytoplasma by nested PCR assays using two universal primer pairs. Phytopatho. Mediter., 35: 144-151.

Kaminska, M., Berniak, H. and Kaminski, P., 2012, Detection of 'Candidatus Phytoplasma asteris' in brussels sprout and Its possible association with flower bud failure in Poland. J. Life Sci., 6: 253-259.

Lee, I. M., Hammond, R. W., Davis, R. E. and Gundersen, D. E. (1993). Universal amplification and analysis of $16 \mathrm{~S}$ rDNA for classification and identification of mycoplasma like organisms. Phytopathol., 83: 834-842.

Madhupriya, Rao, G.P. and Khurana, S. M. (2013). 'Candidatus Phytoplasma asteris' association with leaf yellows and witches' broom symptoms of Brachycome species in India. Phytopatho. Mollicutes., 3(2): 91-94.

Mahadevakumar, S. (2017). Disease of china aster in India. American Phytopathol. Soci., 101: 241.

Namba, S., Kato, S., Iwanamis, S., Oyaizu, H., Shiozawa, H. and Suchizaki, T. (1993). Detection and differentiation of plant-pathogenic mycoplasma like organism using polymerase chain reaction. Phytopatho., 83: 786-791.

Raj, S. K., Khan, M. S., Snehi, S. K.,
Srivastava, S. and Singh, H. B., 2006, 'Candidatus Phytoplasma asteris' isolate associated with a little leaf disease of pigeon pea in India. PlantPathol., 55: 823.

Rangaswamy, K.T., Suryanarayana, V., Muniyappa, V. and Singh, S.J. (1988) Transmission of aster phyllody by Orosius albicinctus. Fitopatologia Brasileira 13: 361- 364.

Schneider, B., Aherns, U., Kirkpatrick, B. C. and Seemuller, E. (1993). Classification of plant-pathogenic mycoplasma-like organisms using restriction site analysis of PCR-amplified 16S rDNA. J. Gen. Microbiol., 139: 519-527.

Singh(2006) Flower Crops: Cultivation and Management. ICAR Publication, New Delhi, pp 61-68.

Smart, C.D., Schneider, B., Blomquist, C.L., Guerra, L. J. and Harrison, N. A. (1996). Phytoplasma-specific PCR primers based on sequences of $16 \mathrm{~S}-23 \mathrm{~S}$ rRNA spacer region. App. Environ. Microbiol., 62: 2988-2993.

Sunard, M., Ben Khalifa, M., Marrakehi. and Fakhfakh. (1991). Detection of phytoplasma associated with periwinkle virescence. Egyp. Plant Pathol., 7(1): 92-97.

\section{How to cite this article:}

Mahalingappa Bandakkanavara, H.A. Prameela, Santosh Mali, Manjunath, S. Hurakadli, S. Basavaraj, Kedarnath, Raghavendra Achari and Rangaswamy, K.T. 2019. Molecular Detection and Characterization of China Aster (Callistephus chinensis L. Nees.) Phyllody Phytoplasma. Int.J.Curr.Microbiol.App.Sci. 8(08): 3070-3076. doi: https://doi.org/10.20546/ijcmas.2019.808.355 